\title{
RAZPRAVE
}

\section{HIDROGEOGRAFSKE ZNAČILNOSTI IN KAKOVOSTNO STANJE VODOTOKOV V POVIRJU REKE}

\author{
AVTORJI \\ Tina Počkar \\ Razguri 16, SI - 6210 Sežana, Slovenija \\ poctina@gmail.com

\section{dr. Gregor Kovačič} \\ Univerza na Primorskem, Fakulteta za humanistične študije, Titov trg 5, SI - 6000 Koper, Slovenija \\ gregor.kovacic@fhs.upr.si
}

\section{Borut Peric}

Javni zavod Park Škocjanske jame, Škocjan 2, SI - 6215 Divača, Slovenija

borut.peric@psj.gov.si

DOI: $10.3986 / G V 86101$

UDK: 911.2:502.51(282)(497.471)

COBISS: 1.01

\section{IZVLEČEK}

Hidrogeografske značilnosti in kakovostno stanje vodotokov $v$ povirju Reke

Članek obravnava hidrogeografske značilnosti povirnega dela Reke. Predstavljene so vodna bilanca in odtočne značilnosti območja. Predstavljeni so rezultati meritev fizikalno-kemijskih parametrov na Reki in izbranih desnih pritokih Reke, opravljenih v štirih različnih vodnih stanjih med avgustom leta 2012 in januarjem leta 2013. Rezultati kažejo, da večina vodotokov nima kraškega zaledja ter, da na kakovost vode v povirju Reke vplivajo neurejene razmere na področju odvajanja odpadnih vod v naseljih.

\section{KLJUČNE BESEDE}

hidrogeografija, onesnaževanje, večparametrske meritve, kakovost vode, Ilirska Bistrica, Reka

\begin{abstract}
Hydrogeographical characteristics and the quality of watercourses in the Reka River headwaters The article deals with hydrogeographical characteristics of the headwaters of the Reka River basin. Its water balance and drainage characteristics are presented. Results of the measurements of physico-chemical parameters in the Reka River and its selected right tributaries, carried out in four different hydrological conditions between August 2012 and January 2013, are presented. The results show, that most of the watercourses don't appear to have karstic characteristics and that the quality of water in the upper course of the Reka basin is highly influenced by uncontrolled wastewater management in the settlements.
\end{abstract}

KEY WORDS

hydrogeography, pollution, multi parametric measurements, water quality, Ilirska Bistrica, Reka River

Uredništvo je prispevek prejelo 12. marca 2014. 


\section{Uvod}

Porečje Reke je razvito v jugozahodnem delu Slovenije (slika 1). Njegov povirni del je Dleto, kjer se v Reko ali Veliko vodo (»Vjilka vuoda«), kot ji pravijo domačini, združujejo vode, ki pritekajo s številnih grap na flišnih kamninah. Izvirno območje Reke se začne na Hrvaškem. Zgornjemu porečju Reke pripada tudi zahodni del Snežniške planote, od koder se vode podzemno pretakajo proti izvirom njenih desnih pritokov (Hidrografska območja 2011). Čeprav so številni avtorji, na primer Rojšek (1987), Kranjc in Mihevc (1989), Šebenik in Kladnik (1999) ter Kovačič (2001; 2003), nekatere značilnosti povirja Reke opisali v sklopu svojih raziskav, pa je le-to s hidrološkega in hidrogeografskega vidika še dokaj neraziskano.

Namen prispevka je podrobneje predstaviti hidrogeografske značilnosti povirja Reke, posebej značilnosti njenih desnih pritokov ter ugotoviti, ali izkazujejo značilnosti kraških izvirov. Hkrati podajamo oceno njihovega kakovostnega stanja, kot tudi oceno kakovostnega stanja Reke v zgornjem toku. Vasi, skozi katere tečejo desni pritoki Reke v povirju, namreč še nimajo urejenih kanalizacijskih omrežij, kar predstavlja potencialno tveganje za kakovost omenjenih vodotokov in Reke.

\section{Metodologija}

Vir meteoroloških in hidroloških podatkov je bila Agencija Republike Slovenije za okolje. Nekatere podatke smo pridobili tudi na spletnih straneh Geodetske uprave Republike Slovenije in Geološkega zavoda Slovenije. Izračuni ocene vodne bilance so bili narejeni s pomočjo orodij v programu ArcGIS 9.3. $S$ tem programskim orodjem pa so bili izdelani tudi zemljevidi.

Terensko delo je obsegalo meritve kakovostnega stanja vode in zajem vzorcev za fizikalno-kemijske analize na devetnajstih lokacijah. Od avgusta 2012 do januarja 2013 smo ob različnih vodnih stanjih izvedli štiri meritve fizikalno-kemijskih parametrov na desetih pritokih Reke: na Sevščku, Potoku v Podgrajah, Vikerniku, Potoku v Trpčanah, Bobniškem potoku, Goričniku, neimenovanem potoku v Vrbici, Vrbovskem potoku, prvem Jarku v Jasenu in Pili, s tem, da smo na pritokih, ki tečejo skozi naselja, meritve in vzorčenja opravili tako gorvodno kot tudi dolvodno od naselij. Hkrati smo merili tudi kakovost Reke. Merilni mesti na Reki sta bili v Dletu in pri Novakovem mlinu dolvodno od Ilirske Bistrice, kjer Reka že zapusti povirni del. $\mathrm{V}$ času pretočnih viškov smo meritve opravili takoj po obilnejših padavinah.

Uporabili smo dve prenosni merilni napravi, večparametrsko sondo Hydrolab MS5, s katero smo merili temperaturo, specifično električno prevodnost (SEP), $\mathrm{pH}$ in vsebnost nitratov, ter merilec vsebnosti raztopljenega kisika v vodi (Oxi 315i DurOx 325). Odvzete vzorce vode smo analizirali s pomočjo prenosnega laboratorija MACHEREY-NAGEL visocolor ECO Analysenkoffer. Določali smo vsebnost nitratov, amonijevih ionov, fosfatov ter celokupno in karbonatno trdoto vode. Kakovost vodotokov smo opredelili na podlagi mejnih vrednosti fizikalno-kemijskih parametrov, določenih v posameznih zakonskih določilih (Zakon o vodah 2002; Pravilnik o pitni vodi 2004; Uredba o emisiji ... 2005; Uredba o oskrbi ...2012) ter po Urbaniču in Tomanu (2003), ki podajata mejne vrednosti parametrov v odvisnosti od vzroka onesnaženja površinskih voda.

\section{Hidrogeološke in hidrološke značilnosti povirja Reke}

Povirje Reke od izvira do njenega sotočja z Moljo meri 143,3 km² in predstavlja 31,7\% celotnega porečja Reke v Sloveniji (Hidrografska območja 2011). Del povirja na hrvaški strani (3-4 km² v flišnih kamninah) v tej številki ni upoštevan. Največji del povirja pripada zakraseli Snežniški planoti, kjer je

Slika 1: Hidrogeološka karta povirja Reke v Sloveniji. 


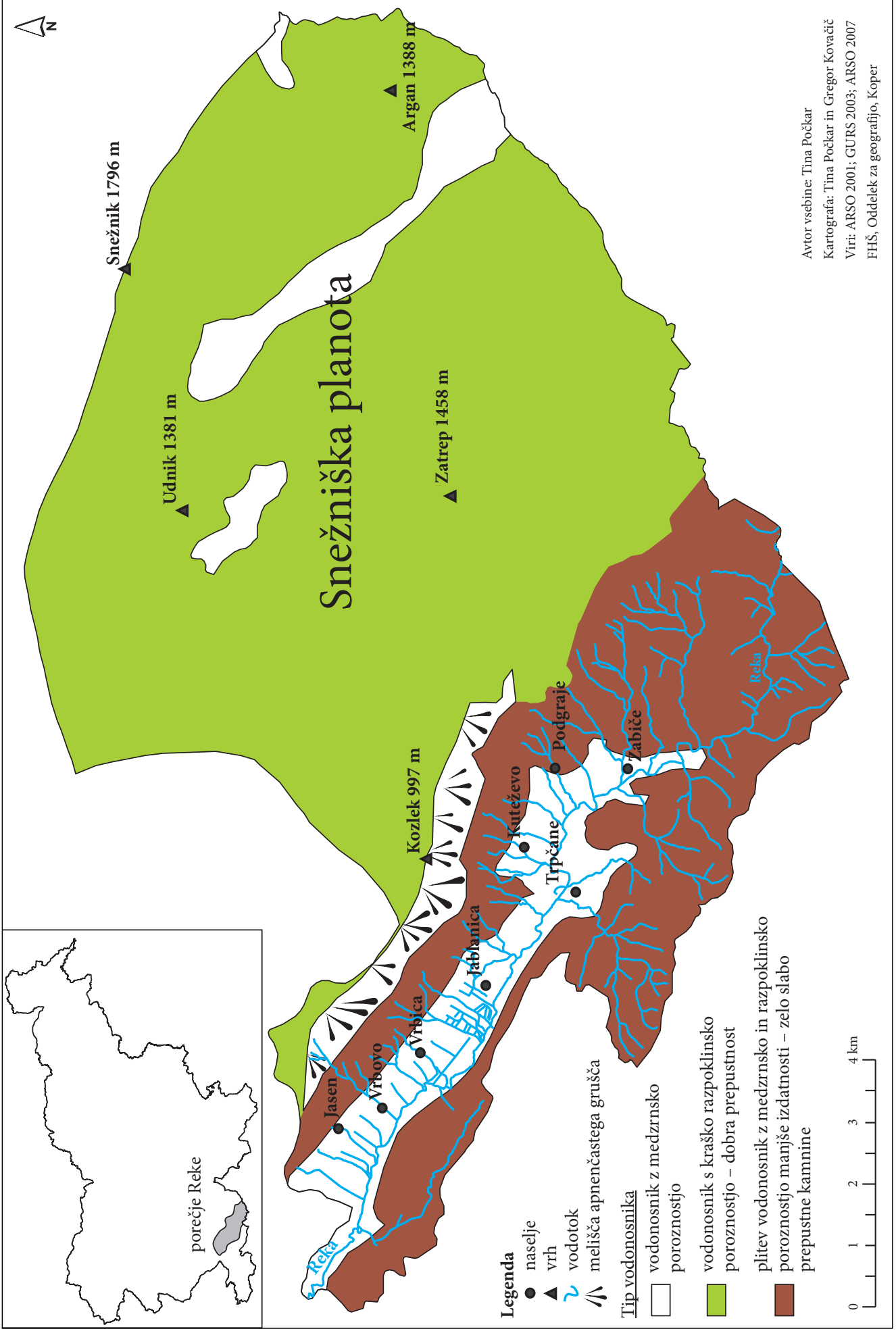


zaradi kraškega površja hidrološka razvodnica težko določljiva. S Snežniške planote podzemne vode namreč odtekajo $\mathrm{v}$ različne smeri, tako $\mathrm{v}$ jadransko kot $\mathrm{v}$ črnomorsko povodje. Iz obravnavanega dela Snežniške planote, natančneje njegovega jugovzhodnega dela, vode podzemno odtekajo tudi v porečje Riječine na Hrvaškem (Kovačič 2003; Petrič 2009; Ravbar 2011). Snežniško planoto gradijo pretežno kredni in jurski apnenci. Globoki kras s kraško razpoklinsko poroznostjo in dobro prepustnostjo omogoča, da padavine hitro poniknejo $\mathrm{v}$ podzemlje in napajajo obsežen kraški vodonosnik, z značilnim pojavom izdatnejših kraških izvirov na njegovem obrobju (Ravbar 2011). Gre za najpomembnejše vodozbirno območje v povirnem delu. Topografska razvodnica povirja Reke je enostavno določljiva na njegovi levi meji, na območju Jelšanskih brd.

Na jugu in zahodu se Snežniška planota v izraziti stopnji prevesi v dolino Reke, ki jo pokrivajo eocenski flišni sedimenti. Ravnico ob Reki in njenih večjih pritokih prekrivajo kvartarni rečni nanosi, v katerih je razvit vodonosnik z medzrnsko poroznostjo (Šikić, Pleničar in Šparica 1972; Šikić in Pleničar 1975). V flišnih kamninah je oblikovan plitev vodonosnik z medzrnsko in razpoklinsko poroznostjo majhne izdatnosti z lokalnimi ali omejenimi viri podzemne vode (Hidrogeološke značilnosti 2007).

Rečna mreža je na vododržnih kamninah dobro razvita. Če upoštevamo vse nestalne vodne tokove je gostota rečne mreže $2,4 \mathrm{~km}$ vodnih tokov na $\mathrm{km}^{2}$ (Digitalne informacije o vodah 2001). Reka ima dežni režim (z odtenki dežno-snežnega režima s sredozemskim poudarkom) (Frantar in Hrvatin 2005). Visoke vode se pojavljajo od novembra do aprila, $\mathrm{z}$ viškom v novembru, nizke pa od maja do septembra, z izrazitim nižkom v juliju (Kolbezen in Pristov 1998; Plut 2000; Frantar in Hrvatin 2005; Frantar 2007). $\mathrm{Na}$ vodomerni postaji Trpčane je srednji letni pretok $1,32 \mathrm{~m}^{3} / \mathrm{s}$, najmanjši le $0,0 \mathrm{~m}^{3} / \mathrm{s}$, največji pa $139 \mathrm{~m}^{3} / \mathrm{s}$ (obdobje 2000-2010). Reka ima hudourniški značaj in se zelo hitro odzove na močne padavine, kar dokazuje razmerje med povprečnim letnim največjim in najmanjšim pretokom, ki znaša 1:105 (Podatki o srednjih ... 2012). Vsaj enkrat letno Reka v povirnem delu tudi poplavlja (Kranjc in Mihevc 1989).

\subsection{Odtočne značilnosti in vodna bilanca}

S celotnega povirnega dela Reke povprečno letno odteče približno $1600 \mathrm{~mm}(69 \%)$ ali $229.000 .000 \mathrm{~m}^{3}$ $\left(51 \mathrm{l} / \mathrm{s} / \mathrm{km}^{2}\right)$ vode, samo z območja z razvito rečno mrežo pa $1130 \mathrm{~mm}(61 \%)$ ali $54.320 .000 \mathrm{~m}^{3}\left(36 \mathrm{l} / \mathrm{s} / \mathrm{km}^{2}\right)$ vode (Raster specifičnega odtoka ... 2008). Odtočni količnik je v obeh primerih velik zaradi velike količine padavin in sredozemskega padavinskega režima (višek padavin je v jesenskim mesecih, ko je izhlapevanje manjše). Na območju Snežniške planote ( $2300 \mathrm{~mm}$ padavin letno) k povečanemu odtoku prispeva tudi zakraselost (zelo prepustna karbonatna kamninska podlaga omogoča hitro pronicanje vode v podzemlje) ter zaradi nižjih temperatur (večje nadmorske višine) nekoliko skromnejše izhlapevanje. Na območju z razvito rečno mrežno v povprečju letno pade okrog $1800 \mathrm{~mm}$ padavin (Povprečna letna ... 2007; Raster realne evapotranspiracije ... 2008).

\subsection{Desni pritoki Reke in njihova porečja}

Reka ima v povirnem delu 27 desnih pritokov (preglednica 1). Dolžine vodnih tokov večinoma ne presegajo 2 km. Najdaljši so: Kolaški potok (3,2 km), Sevšček (1,9km), Potok v Podgrajah $(2 \mathrm{~km})$ in Vrbovski potok $(1,9 \mathrm{~km})$. Večina njihovih izvirov je $\mathrm{v}$ točkah slabše prepustnosti $\mathrm{v}$ apnenčastem pobočnem grušču (Kovačič 2003). Zaradi reliefnih značilnosti so strmci pritokov zelo veliki, kar se odraža v njihovi veliki erozijski moči, čeprav so malo vodnati. Največje strmce imajo pritoki v Dletu (do 263,3 \%o), Bobniški potok (120\%o), Goričnik (100,6\%o) in Vrbovski potok $(120 \%$ ), najmanjšega pa Pila (29,4\%o). Večina pritokov teče le spomladi in jeseni oziroma v času obilnejših padavin, medtem ko so stalni oziroma skoraj stalni le trije nekoliko večji: Kolaški potok, Sevšček, Potok v Podgrajah in en manjši: Pila. Pretoki desnih pritokov nisi poznani, razen ocena izdatnosti izvira pritoka Hrvatice, ki je zajet za vodooskrbni sistem Kuteževo in katerega minimalna izdatnost znaša 0,3 1/s (Digitalne informacije o vodah 2001). 


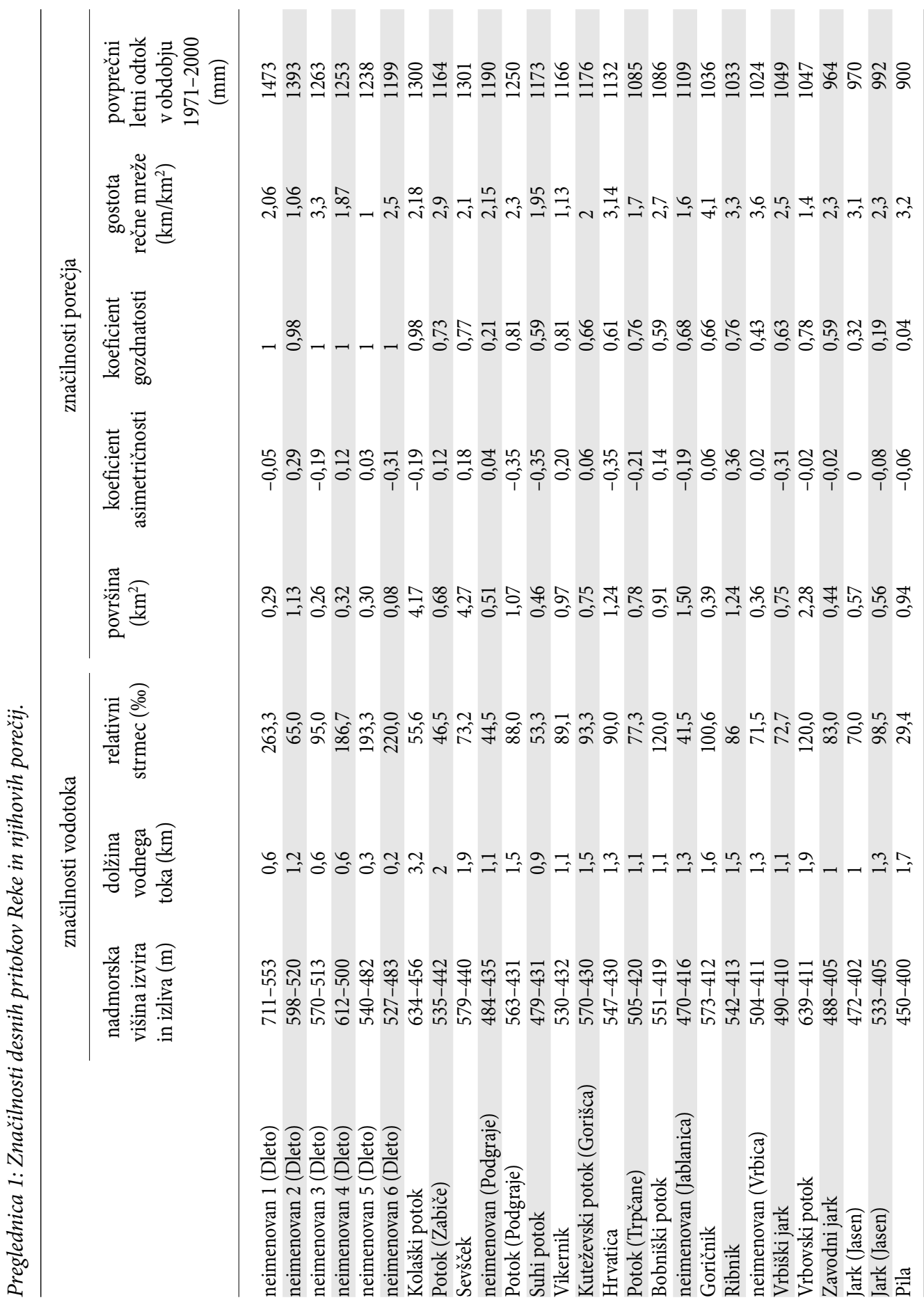


Površine porečij desnih pritokov, ki smo jih določili na podlagi digitalnega modela višin (2005) in sloja vodotokov (Digitalne informacije o vodah 2001) s pomočjo orodja ArcHydro v programu ArcGIS, so med 0,08 in $4,27 \mathrm{~km}^{2}$. Največje je porečje Sevščka. Ker upošteva hidrografski model le površinski odtok vode, in ne tudi podzemeljskega, smo območja prispevnih površin omejili s potekom topografske razvodnice med Snežniško planoto in dolino Reke. Ta poteka po kraškem robu Snežniške planote v dinarski smeri (Razvodnice 2007). Mogoče je, da se porečja nekaterih desnih pritokov deloma nadaljujejo še v kraško-razpoklinski vodonosnik Snežniške planote, pri večini njih pa lahko z veliko gotovostjo trdimo, da ne (Kovačič 2003).

\section{4 Človekovi posegi v vodotoke v povirju Reke}

V povirju Reke živi 2681 prebivalcev v desetih vaseh. Od vzhoda proti zahodu si sledijo Zabiče, Podgraje, Kuteževo, Trpčane, Jablanica, Vrbica, Vrbovo in Jasen, na levem bregu Reke pa sta naselji Dolnji Zemon in Koseze. Vasi so gručaste, večinoma odmaknjene na stik ravnine in pobočij ali celo na vznožje pobočij (Državna topografska karta ... 2003; Prebivalstvo ... 2012).

Med najstarejše posege v vodotoke $\mathrm{v}$ povirju Reke štejemo izgonske struge desnih pritokov Reke med Zabičami in Ilirsko Bistrico, ki so danes na nekaterih odsekih vodotokov še vedno ohranjene. Druge regulacije so tu še mostovi, prepusti, spremenjene struge vodotokov skozi večino vasi (struge so utrjene ali obložene s kamenjem, ponekod $\mathrm{z}$ betonom), izravnave ter upočasnitev toka na Reki med Zabičami in Trpčanami (bregovi so nasuti s prodom, izkopanim pri poglabljanju struge in s kovinsko mrežo ter lesenimi objekti), in umetni rečni okljuk na Reki zahodno od naselja Vrbovo. Med obsežnejše regulacije v povirju sodijo hidromelioracije in komasacije kmetijskih zemljišč v krajevni skupnosti Jasen, ki so jih pred več desetletji izvedli z namenom izboljšanja vodnih značilnosti tal; voda je namreč na zemljiščih zastajala.

Med potencialne onesnaževalce vodotokov v povirju Reke uvrščamo neurejene razmere na področju odvajanja in čiščenja odpadnih vod, promet, kmetijsko in gozdarsko dejavnost ter divja odlagališča odpadkov. Neurejeno odvajanje odpadnih voda predstavlja zelo resno nevarnost za onesnaženje vodotokov, še posebej tam, kjer so odtočne cevi speljane neposredno v vodotoke. Z izjemo Jasena, v ostalih naseljih v povirju Reke kanalizacijsko omrežje ni zgrajeno. V naseljih so zgrajeni le odtoki meteornih vod. Nekatere hiše sploh nimajo greznic oziroma imajo greznice pretočnega tipa; ponekod so odpadne vode iz njih speljane neposredno v vodotoke. Vprašljiva je tudi vodotesnost greznic.

Vsa naselja na desnem bregu Reke, razen Jasena, ki je vezan na regionalni bistriški vodovod, za potrebe pitne vode na voljo tudi svoje lokalne vodooskrbne sisteme, za katere je zajetih 17 izvirov, ki še nimajo določenih vodovarstvenih pasov ter režima varovanja kakovosti in zalog pitne vode (Kovačič 2001).

\section{Kakovostno stanje desnih pritokov Reke}

Iz preglednice 2 je razviden potek meritev na Reki in pritokih. Prve meritve so bile opravljene v času poletne suše in pretočnih nižkov. Od izbranih vodotokov je 31. avgusta poleg Reke tekla voda le še v Pili, vsi ostali vodotoki pa so bili suhi. Na dan meritev je bil na vodomerni postaji Trpčane povprečni dnevni pretok le $0,05 \mathrm{~m}^{3} / \mathrm{s}$, na vodomerni postaji Trnovo pa $0,48 \mathrm{~m}^{3} / \mathrm{s}$ (Podatki o dnevnih pretokih ... 2013). Druge meritve so bile opravljene po prvem obilnejšem deževju po daljšem sušnem obdobju, 17. ter deloma še 18. oktobra 2012. Obilnejše padavine so nastopile 15. oktobra popoldne, preko noči

Slika 2: Regulacije na desnih pritokih Reke in merilne točke kakovosti vodotokov v njenem povirju v obdobju od avgusta 2012 do januarja 2013. 


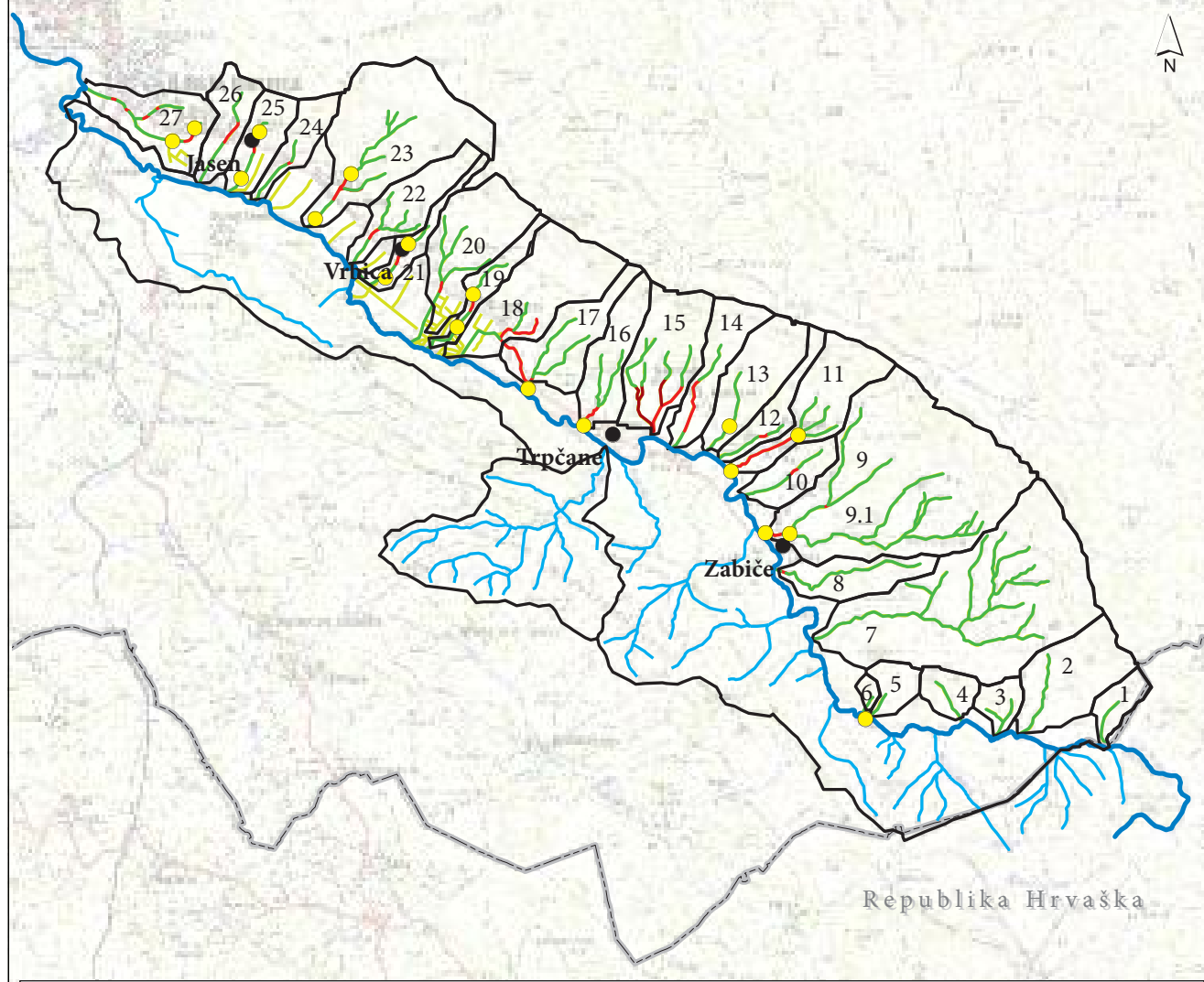

\section{Legenda}

merilno mesto

- naselje

--- državna meja

$\sim$ reka

$\sim$ levi pritok

Desni pritok - regulacije

$\frown$ naravna struga

$\frown$ regulirana struga

$\sim$ struga regulirana $\mathrm{v}$ preteklosti

_ melioracijski oziroma drenažni jarek

\section{— razvodnica}

$\square$ porečje desnega pritoka

Ime desnega pritoka

1 - neimenovan

2 - neimenovan

3 - neimenovan

4 - neimenovan

5 - neimenovan

6 - neimenovan

7 - Kolaški potok

8 - Potok
9 - Sevšček

9.1 - Malenšček

10 - neimenovan

11 - Potok

12 - Suhi potok

13 - Vikernik

14 - Kuteževski potok (Gorišca)

15 - Hrvatica

16 - Potok

17 - Bobniški potok

18 - neimenovan

19 - Goričnik (Grdi jark)

20 - Ribnik

21 - neimenovan

22 - Vrbiški jark

23 - Vrbovski potok

24 - Zavodni jark

25 - Jark

26 - Jark

27 - Pila

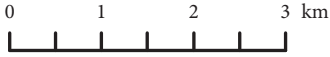

Avtor: Tina Počkar Kartograf: Tina Počkar

Vir: ARSO 2001; GURS 2003; ARSO 2007 FHŠ, Oddelek za geografijo, Koper 
Preglednica 2: Rezultati meritev fizikalno-kemijskih parametrov na Reki in izbranih desnih pritokih.

\begin{tabular}{|c|c|c|c|c|c|c|c|c|c|c|c|c|}
\hline \multirow{2}{*}{$\begin{array}{l}\text { parameter } \\
\text { merilno mesto }\end{array}$} & \multicolumn{4}{|c|}{$\mathrm{T}\left({ }^{\circ} \mathrm{C}\right)$} & \multicolumn{4}{|c|}{$\mathrm{pH}$} & \multicolumn{4}{|c|}{$\operatorname{SEP}(\mu \mathrm{S} / \mathrm{cm})$} \\
\hline & 31.8. & $\begin{array}{c}17 . / 18 . \\
10 .\end{array}$ & $\begin{array}{c}6 . / 7 . \\
11 .\end{array}$ & 23.1. & 31.8. & $\begin{array}{c}17 . / 18 . \\
10 .\end{array}$ & $\begin{array}{c}6 . / 7 . \\
11 .\end{array}$ & 23.1 . & 31.8 . & $\begin{array}{c}17 . / 18 . \\
10 .\end{array}$ & $\begin{array}{c}6 . / 7 . \\
11 .\end{array}$ & 23.1 . \\
\hline Reka - Dleto & 16,2 & 10,6 & 10,8 & 6,2 & 7,8 & 7,7 & 7,6 & 7,7 & 257 & 153 & 118 & \\
\hline Sevšček - nad naseljem & I & 12,7 & 11,3 & 6,0 & l & 7,9 & 7,9 & 7,8 & l & 386 & 313 & \\
\hline Sevšček - pod naseljem & I & 12,9 & 11,4 & 6,0 & l & 7,8 & 7,8 & 7,8 & l & 415 & 329 & \\
\hline Potok Podgarje - nad naseljem & I & 12,4 & 11,0 & 6,3 & l & 8,3 & 8,1 & 8,1 & l & 419 & 374 & \\
\hline Potok Podgraje - pod naseljem & I & 15,1 & 11,4 & 5,9 & l & 7,4 & 7,9 & 7,8 & l & 581 & 403 & \\
\hline Vikernik & 1 & 12,7 & 11,3 & 6,7 & I & 7,7 & 7,7 & 7,9 & I & 436 & 379 & \\
\hline Potok Trpčane & l & 13,8 & 11,8 & 5,4 & l & 7,8 & 7,8 & 7,8 & l & 689 & 568 & \\
\hline Bobniški potok & I & 14,3 & 12,0 & 5,6 & l & 7,6 & 7,6 & 7,7 & 1 & 334 & 487 & \\
\hline Goričnik - nad naseljem & I & l & 11,8 & 5,8 & l & l & 7,7 & 7,9 & l & l & 597 & \\
\hline Goričnik - pod naseljem & l & l & 12,0 & 5,9 & l & l & 7,8 & 8,1 & l & l & 586 & 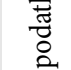 \\
\hline
\end{tabular}

$\begin{array}{lcccccccccccc}\begin{array}{l}\text { neimenovan Vrbica - } \\ \text { nad naseljem }\end{array} & / & 12,5 & 11,5 & 6,9 & / & 7,5 & 7,3 & 7,6 & / & 448 & 469 \\ \begin{array}{l}\text { neimenovan Vrbica - } \\ \text { pod naseljem }\end{array} & / & 14,7 & 12,8 & 6,6 & / & 7,7 & 7,7 & 7,8 & / & 671 & 595 \\ \begin{array}{l}\text { Vrbovski potok - nad naseljem } \\ \text { Vrbovski potok - pod naseljem }\end{array} & / & 13,4 & 10,2 & 7,0 & / & 7,7 & 8.0 & 8.0 & / & 593 & 469 \\ & / & 13,5 & 9,9 & 7,1 & / & 8,1 & 8.0 & 8,1 & / & 547 & 454 \\ \text { Jark 1 - nad naseljem } & / & 9,9 & 9,4 & 8,3 & / & 8,2 & 8,1 & 8,1 & / & 361 & 363 \\ \text { Jark 1 - pod naseljem } & / & 10,7 & 9,8 & 8,0 & / & 8 & 8,1 & 8,1 & / & 390 & 372 \\ \text { Pila - nad naseljem } & / & 8,8 & 8,7 & 9,0 & / & 8,1 & 7,9 & 8,1 & / & 341 & 325 \\ \text { Pila - pod naseljem } & 17,9 & 9,2 & 8,8 & 8,6 & 7,1 & 8.0 & 7,9 & 7,8 & 415 & 365 & 325 \\ \text { Reka - Novakov mlin } & 17,2 & 10,5 & 10,3 & 6,2 & 7,3 & 7,9 & 7,5 & 7,6 & 318 & 362 & 295\end{array}$

0 - pod mejo določitve

I - meritev ni bila opravljena 


\begin{tabular}{|c|c|c|c|c|c|c|c|c|c|c|c|c|c|c|c|}
\hline \multicolumn{4}{|c|}{$\mathrm{O}_{2}(\mathrm{mg} / \mathrm{l}) /$ nasičenost $(\%)$} & \multicolumn{4}{|c|}{$\mathrm{NO}_{3}^{-}(\mathrm{mg} / \mathrm{l})$} & \multicolumn{4}{|c|}{$\mathrm{NH}_{4}^{+}(\mathrm{mg} / \mathrm{l})$} & \multicolumn{4}{|c|}{$\mathrm{PO}_{4}-\mathrm{P}(\mathrm{mg} / \mathrm{l})$} \\
\hline 31.8 . & $\begin{array}{c}17 . / 18 . \\
10 .\end{array}$ & $\begin{array}{c}6 . / 7 . \\
11 .\end{array}$ & 23. 1 . & 31.8 . & $\begin{array}{c}17 . / 18 . \\
10 .\end{array}$ & $\begin{array}{c}6 . / 7 . \\
11 .\end{array}$ & 23.1. & 31.8 & $\begin{array}{c}17 . / 18 . \\
10 .\end{array}$ & $\begin{array}{c}6 . / 7 . \\
11 .\end{array}$ & 23.1. & 31.8 . & $\begin{array}{c}17 . / 18 . \\
10 .\end{array}$ & $\begin{array}{c}6 . / 7 . \\
11 .\end{array}$ & 23.1. \\
\hline $\begin{array}{l}1,9 / \\
19,2\end{array}$ & $\begin{array}{l}11,4 / \\
102,2\end{array}$ & $\begin{array}{l}11,4 / \\
102,7\end{array}$ & $\begin{array}{l}11,4 / \\
92,0\end{array}$ & 0,26 & 1,26 & 4,0 & 5,0 & 0 & 0 & 0 & 0 & 0 & 0 & 0,3 & 0 \\
\hline 1 & $\begin{array}{l}10,7 / \\
99,0\end{array}$ & $\begin{array}{l}11,0 / \\
102,3\end{array}$ & $\begin{array}{l}11,6 / \\
93,2\end{array}$ & 1 & 4,14 & 5,0 & 6,0 & 1 & 0 & 0 & 0 & 1 & 0 & 0 & 0 \\
\hline 1 & $\begin{array}{l}10,5 / \\
99,1\end{array}$ & $\begin{array}{l}11,2 / \\
102,3\end{array}$ & $\begin{array}{l}11,6 / \\
93,2\end{array}$ & 1 & 4,95 & 7,0 & 6,0 & 1 & 0 & 0 & 0 & 1 & 0,5 & 0 & 0 \\
\hline 1 & $\begin{array}{l}11,3 / \\
106,3\end{array}$ & $\begin{array}{l}11,3 / \\
102,2\end{array}$ & $\begin{array}{l}11,8 / \\
95,5\end{array}$ & 1 & 5,69 & 6,0 & 6,0 & 1 & 0 & 0 & 0 & 1 & 0 & 0 & 0 \\
\hline 1 & $\begin{array}{l}7,9 / \\
78,1\end{array}$ & $\begin{array}{l}10,5 / \\
95,8\end{array}$ & $\begin{array}{l}11,4 / \\
91,3\end{array}$ & 1 & 12,4 & 10,0 & 8,0 & 1 & 0,3 & 0,1 & 0,1 & 1 & 0,4 & 0,1 & 0 \\
\hline 1 & $\begin{array}{l}10,8 / \\
101,5\end{array}$ & $\begin{array}{l}11,2 / \\
102,0\end{array}$ & $\begin{array}{l}11,4 / \\
93,2\end{array}$ & 1 & 5,76 & 7,0 & 7,0 & 1 & 0 & 0 & 0 & 1 & 0 & 0 & 0 \\
\hline 1 & $\begin{array}{l}10,4 / \\
100,0\end{array}$ & $\begin{array}{l}10,8 / \\
99,5\end{array}$ & $\begin{array}{c}12 / \\
94,9\end{array}$ & 1 & 3,96 & 5,0 & 6,0 & 1 & 0 & 0 & 0 & 1 & 0,2 & 0 & 0 \\
\hline 1 & $\begin{array}{l}9,1 / \\
88,5\end{array}$ & $\begin{array}{l}9,7 / \\
89,7\end{array}$ & $\begin{array}{l}11,3 / \\
89,8\end{array}$ & 1 & 4,28 & 6,0 & 6,0 & 1 & 0 & 0 & 0 & 1 & 0 & 0 & 0 \\
\hline 1 & 1 & $\begin{array}{l}10,6 / \\
97,7\end{array}$ & $\begin{array}{l}11,7 / \\
93,5\end{array}$ & 1 & 1 & 4,0 & 4,0 & 1 & 1 & 0 & 0 & 1 & 1 & 0 & 0 \\
\hline 1 & 1 & $\begin{array}{l}8,7 / \\
80,5\end{array}$ & $\begin{array}{l}11,2 / \\
89,7\end{array}$ & 1 & 1 & 4,0 & 5,0 & 1 & 1 & 0 & 0 & 1 & 1 & 0 & 0 \\
\hline 1 & $\begin{array}{l}11,3 / \\
105,7\end{array}$ & $\begin{array}{l}11,1 / \\
100,6\end{array}$ & $\begin{array}{l}11,1 / \\
91,2\end{array}$ & 1 & 0,76 & 5,0 & 5,0 & 1 & 0 & 0 & 0 & 1 & 0 & 0 & 0 \\
\hline 1 & $\begin{array}{l}6,4 / \\
62,8\end{array}$ & $\begin{array}{l}7,9 / \\
74,4\end{array}$ & $\begin{array}{l}9,8 / \\
79,9\end{array}$ & 1 & 6,3 & 10,0 & 9,0 & 1 & 0,5 & 0,2 & 0,1 & 1 & 0,4 & 0,1 & 0 \\
\hline 1 & $\begin{array}{l}10,7 / \\
102,1\end{array}$ & $\begin{array}{l}11,7 / \\
103,9\end{array}$ & $\begin{array}{l}11,5 / \\
94,7\end{array}$ & 1 & 5,2 & 4,0 & 5,0 & 1 & 0 & 0 & 0 & 1 & 0 & 0 & 0 \\
\hline 1 & $\begin{array}{l}10,3 / \\
98,5\end{array}$ & $\begin{array}{l}11,7 / \\
103,2\end{array}$ & $\begin{array}{l}11,7 / \\
96,6\end{array}$ & 1 & 5,09 & 5,0 & 5,0 & 1 & 0 & 0 & 0 & 1 & 0,2 & 0 & 0 \\
\hline 1 & $\begin{array}{l}11,7 / \\
96,6\end{array}$ & $\begin{array}{l}12,5 / \\
109,0\end{array}$ & $\begin{array}{l}11,2 / \\
95,2\end{array}$ & 1 & 2,2 & 7,0 & 5,0 & 1 & 0 & 0 & 0 & 1 & 0 & 0 & 0 \\
\hline 1 & $\begin{array}{l}10,0 / \\
89,8\end{array}$ & $\begin{array}{l}11,7 / \\
103,0\end{array}$ & $\begin{array}{l}10,8 / \\
91,1\end{array}$ & 1 & 2,43 & 7,0 & 6,0 & 1 & 0 & 0 & 0 & 1 & 0,1 & 0 & 0 \\
\hline 1 & $\begin{array}{l}12,2 / \\
104,9\end{array}$ & $\begin{array}{c}12,5 / \\
107,2\end{array}$ & $\begin{array}{l}11,1 / \\
95,9\end{array}$ & 1 & 2,71 & 7,0 & 7,0 & 1 & 0 & 0 & 0 & 1 & 0 & 0 & 0 \\
\hline $\begin{array}{l}2,7 / \\
28,3\end{array}$ & $\begin{array}{l}11,5 / \\
99,9\end{array}$ & $\begin{array}{l}12,1 / \\
104,0\end{array}$ & $\begin{array}{l}10,6 / \\
90,7\end{array}$ & 0,13 & 2,63 & 7,0 & 7,0 & 0,1 & 0 & 0 & 0 & 0,2 & 0 & 0 & 0 \\
\hline $\begin{array}{l}2,4 / \\
24,8\end{array}$ & $\begin{array}{l}11,3 / \\
101,1\end{array}$ & $\begin{array}{l}11,0 / \\
98,0\end{array}$ & $\begin{array}{l}11,6 / \\
93,6\end{array}$ & 0,9 & 3,87 & 8,0 & 7,0 & 3.0 & 0 & 0 & 0 & 0,3 & 0 & 0 & 0 \\
\hline
\end{tabular}


s 15. na 16. oktober pa je dež postopoma ponehal $(116 \mathrm{~mm}$ na Mašunu, $76 \mathrm{~mm}$ na Jurščah in $22 \mathrm{~mm}$ v Podgradu) (Podatki o dnevnih padavinah ... 2013). Na vodomerni postaji Trnovo je bil na dan meritev 17. oktobra povprečni dnevni pretok Reke $13,6 \mathrm{~m}^{3} / \mathrm{s}$, dan zatem pa $10,8 \mathrm{~m}^{3} / \mathrm{s}$ (Podatki o dnevnih pretokih ... 2013). V obdobju med 27. oktobrom in 6. novembrom je na Mašunu padlo $366 \mathrm{~mm}$, na Jurščah $232 \mathrm{~mm}$ in v Podgradu $241 \mathrm{~mm}$ padavin (Podatki o dnevnih padavinah ... 2013). Meritve smo opravili 6. ter deloma 7. novembra 2012. 6. novembra je bil povprečni dnevni pretok Reke na vodomerni postaji Trpčane $7,7 \mathrm{~m}^{3} / \mathrm{s}$, na vodomerni postaji Trnovo pa $21,7 \mathrm{~m}^{3} / \mathrm{s}$. Naslednji dan je povprečni dnevni pretok na slednji upadel na $17,3 \mathrm{~m}^{3} / \mathrm{s}$ in je še naprej upadal (Podatki o dnevnih pretokih ... 2013). Zadnje meritve so bile opravljene 23. januarja 2013 po daljšem obdobju manj intenzivnih padavin, ki je trajalo od 13. do 24. januarja. V tem obdobju je na Mašunu padlo 108, na Jurščah 86 in v Podgradu 149 mm padavin (Podatki o dnevnih padavinah ... 2013). Na dan meritev je bil povprečni dnevni pretok na vodomerni postaji Trpčane $1,43 \mathrm{~m}^{3} / \mathrm{s}$ (Podatki o dnevnih pretokih ... 2013).

\subsection{Temperatura, $\mathrm{pH}$ in SEP}

Pričakovano so meritve temperature vode pokazale sezonsko in dnevno nihanje. $Z$ meritvami smo vedno začeli v zgornjem toku Reke v Dletu in se pomikali dolvodno do Novakovega mlina, kar ima vpliv na rezultate. Dnevni in letni temperaturi režim vode na izviru sta lahko dobra pokazatelja, ali gre za kraški ali nekraški vodni tok. Najmanjši letni razpon smo zabeležili pri Jarku 1 in Pili nad naseljema. V Jarku 1 nad naseljem so bile izmerjene vrednosti v razponu $8,3-9,9^{\circ} \mathrm{C}$, v Pili nad naseljem pa med $8,8-9^{\circ} \mathrm{C}$. Na podlagi temperaturnih značilnosti lahko sklepamo, da se omenjena desna pritoka Reke polnita iz kraško-razpoklinskega vodonosnika Snežniške planote, saj kažeta podobne temperaturne značilnosti kot kraški izviri, ki pritekajo iz globokega krasa, kjer letna temperatura navadno niha za manj kot $1{ }^{\circ} \mathrm{C}$ (Gams 2003). Pri ostalih pritokih so bila izmerjena večja letna nihanja temperature voda, kar je značilnost vodotokov z nekraškim izvirom.

Vrednosti $\mathrm{pH}$, ki so se na merilnih mestih gibale med 7,1 in 8,3, pričakovano kažejo na bazičnost vod. Med posameznimi meritvami se vrednosti na merilnih mestih niso bistveno razlikovale. Tudi med vrednostmi $\mathrm{pH}$ na potokih nad in pod naselji so bile razlike zelo majhne, z izjemo na potoku v Podgrajah, kjer so bile ob vseh meritvah, razen v avgustu, ko je bil potok suh, vrednosti $\mathrm{pH}$ pod naseljem nižje od tistih nad naseljem. V oktobru je bila razlika največja, saj je bila nad naseljem izmerjena vrednost $\mathrm{pH} 8,3$, pod naseljem pa le 7,4. Razloge lahko iščemo v onesnaženju.

Najnižje vrednosti SEP so bile izmerjene na Reki $(118-362 \mu \mathrm{S} / \mathrm{cm})$. Majhne vsebnosti raztopljenih snovi v Reki v njenem povirju kažejo, da se padavine zelo malo časa zadržijo v preperelinskem in prstenem pokrovu, ki sta v povirju Reke zelo tanka, ponekod pa v celoti odsotna, in da je odtok vode iz povirja hiter. 6 . novembra 2012, po daljšem padavinskem obdobju, smo tako na Reki v Dletu izmerili najnižjo vrednost SEP $(118 \mu \mathrm{S} / \mathrm{cm})$. Pri desnih pritokih Reke so vrednosti SEP v razponu od 313 do kar $689 \mu \mathrm{S} / \mathrm{cm}$. Vzrok za to gre pripisati večji vsebnosti kalcijevih, magnezijevih in hidrogenkarbonatnih ionov v vodah, ki izvirajo iz apnenčastega grušča, v katerem se zadržujejo nekoliko dlje. Vrednosti SEP kažejo na značilno nihanje v odvisnosti od trenutnih vodnih razmer; ob nizkem vodostaju so vrednosti značilno višje. Ker je SEP odraz tudi drugih raztopljenih snovi v vodi, se med rezultati kažejo razlike tudi na Reki in pritokih dolvodno (nad in pod naselji). Dolvodno je SEP v vseh primerih, razen pri Vrbovskem potoku in Goričniku, naraščala zaradi kmetijskega onesnaževanja voda ter izlivov odpadnih voda iz naselij. Največja razlika med SEP nad in pod naseljem je bila na neimenovanem pritoku $\mathrm{v}$ Vrbici izmerjena 6 . novembra $(223 \mu \mathrm{S} / \mathrm{cm})$. Dokaj visoke izmerjene vrednosti SEP $(568-689 \mu \mathrm{S} / \mathrm{cm})$ pri nekaterih desnih pritokih (na primer: potok Trpčane, neimenovan Vrbica, Vrbovski potok in Goričnik) lahko vsaj deloma razložimo s hidrološkimi razmerami v času meritev; spiranje starejše, visoko nasičene vode iz sistema po daljšem obdobju brez padavin. Vrednosti SEP najmanj nihajo pri Jarku 1 $(2 \mu \mathrm{S} / \mathrm{cm})$ in Pili nad naseljem $(16 \mu \mathrm{S} / \mathrm{cm})$, kar kaže na bolj stabilno kemijsko sestavo vode omenjenih izvirov ter na njun kraški značaj. 


\subsection{Vsebnost v vodi raztopljenega kisika}

V času avgustovskih meritev so bile vsebnosti kisika v vodi zelo nizke, na Reki v Dletu samo 1,9 mg/l (19,2 \% nasičenost), na Reki pri Novakovem mlinu 2,4 mg/l (24,8\% nasičenost) in v Pili 2,7 mg/l (28,3\% nasičenost), kar je bila posledica visokih temperatur vode in majhnih pretokov. $V$ času drugih meritev se je vsebnost $\mathrm{v}$ vodi raztopljenega kisika povišala in je bila na večini merilnih mest med 9,1 in 11,7 mg/l. Najvišja vsebnost raztopljenega kisika je bila izmerjena v Pili nad naseljem (12,2 mg/l), najnižja pa v Potoku v Podgrajah pod naseljem (7,9 $\mathrm{mg} \mathrm{O}_{2} / 1: 78,1 \%$ nasičenost) in v neimenovanem potoku v Vrbici (6,4 $\mathrm{mg} \mathrm{O}_{2} / 1 ; 62,8 \%$ nasičenost). Vzrok za to gre pripisati večji onesnaženosti vode na teh dveh mestih. Z nižanjem temperatur in večanjem količine padavin so se $\mathrm{v}$ času meritev, ki so sledile, koncentracije $v$ vodi raztopljenega kisika in nasičenost $s$ kisikom na merilnih mestih še povečevale, ponekod pa so bile še opazne razlike med vsebnostmi raztopljenega kisika nad in pod naselji. Najmanj raztopljenega kisika je bilo ob vseh meritvah izmerjenega v neimenovanem potoku pod naseljem Vrbica, kjer vrednosti niso nikoli presegle $9,8 \mathrm{mg} \mathrm{O}_{2} / \mathrm{l}$, nasičenost $\mathrm{s}$ kisikom pa ni presegla $80 \%$.

\subsection{Nitrati, amonijevi ioni in fosfati}

Vsebnosti nitratov so se od avgusta do novembra na Reki in večini pritokov povečevale, januarja pa so bile enake ali nekoliko nižje od novembrskih, kar lahko pripišemo spiranju hranil iz prsti. 31. avgusta vrednosti na Reki in Pili niso presegle mejne vrednosti za neonesnažene vode $(1 \mathrm{mg} / \mathrm{l})$. Ker je bilo takrat padavin zelo malo, še ni prišlo do izpiranja z okoliških zemljišč. Oktobrske vrednosti so bile zaradi padavin, ki so sledile po daljšem sušnem obdobju, večje. Gibale so se do vrednosti $10 \mathrm{mg} / \mathrm{l}$, kar kaže na onesnaževanje s spiranjem gnojenih kmetijskih zemljišč. Izjema je izmerjena vrednost nitratov v Potoku pod vasjo Podgraje, kjer je bilo izmerjenih $12,2 \mathrm{mg} \mathrm{NO}_{3} / \mathrm{l}$ vode, in pomeni tudi onesnaženje iz odpadnih voda (Urbanič in Toman 2003). Novembrske vrednosti so bile še nekoliko višje (razen v Vrbovskem potoku, kjer so vrednosti nekoliko upadle), vendar tudi tokrat pod mejo $10 \mathrm{mg} / \mathrm{l}$. Izjema je bil zopet Potok pod vasjo Podgraje, kjer je bila izmerjena mejna vrednost $10 \mathrm{mg} / \mathrm{l}$, enako je veljalo za potok pod naseljem Vrbica. 23. januarja so se vrednosti nitratov povišale samo na štirih merilnih mestih, v Dletu na Reki, Sevšku nad naseljem, Potoku v Trpčanah in Vrbovskem potoku nad naseljem, na ostalih mestih pa so se znižale ali ostale enake prejšnjim. Na nobenem merilnem mestu vrednosti niso dosegle ali presegle mejne vrednosti $10 \mathrm{mg} / \mathrm{l}$. Najvišja vrednost nitratov je bila izmerjena $\mathrm{v}$ neimenovanem potoku pod naseljem Vrbica, kjer je bilo izmerjenih $9 \mathrm{mg} \mathrm{NO}_{3} / 1$. Največje razlike med vrednostmi v pritokih dolvodno (nad in pod naselji) so se pokazale v Potoku v Podgrajah in neimenovanem potoku v Vrbici. Tu so bile vrednosti pod naseljem ob vseh meritvah višje in so presegale vrednosti pod naselji na drugih pritokih. Poleg onesnaženja s spiranjem s kmetijskih zemljišč se tu kaže tudi onesnaženje z odpadnimi vodami iz naselij. Posledično je bila dolvodno bolj onesnažena tudi Reka.

Koncentracije amonija so bile izmerjene v treh pritokih pod naselji - v Potoku v Podgrajah, neimenovanem potoku v Vrbici in Pili ter v Reki pri Novakovem mlinu. Najvišje koncentracije na Reki so bile izmerjene v avgustu ob nižku, na pritokih, ki so bili v tem času suhi, pa v oktobru, ko je prišlo do prvega večjega izpiranja.

$\mathrm{Na}$ Reki pri Novakovem mlinu so koncentracije 31. avgusta dosegle vrednost $3 \mathrm{mg} / \mathrm{l}$ in s tem presegle običajno vrednost $0,2 \mathrm{mg} / \mathrm{l} \mathrm{v}$ površinskih vodah in mejno vrednost za pitno vodo, ki je $0,50 \mathrm{mg} / \mathrm{l}$ (Urbanič in Toman 2003; Pravilnik o pitni vodi 2004). Ob naslednjih meritvah koncentracije amonija na Reki niso bile več izmerjene. K temu je pripomoglo redčenje po padavinah, ki so sledile. Na pritokih je bila običajna koncentracija amonija v površinskih vodah $(0,2 \mathrm{mg} / \mathrm{l})$ presežena dvakrat, in sicer 17 . oktobra v Potoku v Podgrajah in neimenovanem potoku v Vrbici pod naselji. V Potoku v Podgrajah je bila koncentracija $0,3 \mathrm{mg} / \mathrm{l}, \mathrm{v}$ neimenovanem potoku $\mathrm{v}$ Vrbici pa $0,5 \mathrm{mg} / \mathrm{l}$, kjer je dosegla tudi mejno vrednost za pitno vodo. Ob naslednjih meritvah so bile koncentracije nižje in niso presegle običajne koncentracije v površinskih vodah. Podatki kažejo, da sta pritoka pod naselji onesnažena s kmetijskimi 
in komunalnimi odplakami, kar je v času večjih pretokov zaradi redčenja manj izrazito. V Pili pod naseljem so bile koncentracije amonija izmerjene le v avgustu, ko še ni prišlo do izpiranja, in niso presegale običajne vrednosti v površinskih vodah.

Koncentracije fosfatov so bile izmerjene tako na Reki v Dletu kot pri Novakovem mlinu ter na Sevščku, Potoku v Podgrajah, Potoku v Trpčanah, neimenovanem potoku v Vrbici, Vrbovskem potoku, Jarku 1 $\mathrm{v}$ Jasenu in Pili pod naselji. Tudi v tem primeru so bile na Reki najvišje koncentracije izmerjene v avgustu ob nižku, na pritokih, ki so bili v tem času suhi, pa v oktobru, ko je prišlo do prvega večjega izpiranja; z izjemo v Dletu na Reki, kjer so bile koncentracije najvišje novembra. Na Reki je bilo izmerjenih kar $0,3 \mathrm{mg} \mathrm{PO}-\mathrm{P} / 1$, in sicer 31. avgusta pri Novakovem mlinu in 6. novembra v Dletu. Avgustovske koncentracije pri Novakovem mlinu so bile visoke zaradi nizkih vodostajev, medtem ko je v Dletu prišlo do onesnaženja kasneje. Vsebnosti koncentracij na obeh mestih kažejo na onesnaženje tako iz kmetijskih (Dleto) kot tudi komunalnih in industrijskih odplak (Urbanič in Toman 2003), vendar povečane koncentracije fosfatov $\mathrm{v}$ Dletu težko povežemo $\mathrm{z}$ omenjenimi možnimi vzroki. V Pili pod naseljem so bile koncentracije najvišje avgusta, ko so bili najmanjši pretoki, in so dosegale vrednost $0,2 \mathrm{mg} / \mathrm{l}$, kar pomeni onesnaženje z gnojenih kmetijskih zemljišč. Na ostalih pritokih so bile koncentracije najvišje oktobra, po prvem obilnejšem deževju, ko so kar na petih mestih presegale mejno vrednost $0,1 \mathrm{mg} / \mathrm{l}$, ki je mejna vrednost za neonesnažene vode. Na treh mestih so celo presegale vrednost $0,25 \mathrm{mg} / \mathrm{l}$, ki je mejna vrednost za onesnaženje s spiranjem z gnojenih kmetijskih zemljišč in tako dosegale vrednosti, ki pomenijo onesnaženje iz komunalnih odplak (Urbanič in Toman 2003). Onesnaženje zaradi spiranja s kmetijskih zemljišč je bilo 17. in 18. oktobra prisotno v Potoku pri Trpčanah, Vrbovskem potoku in Jarku $1 \mathrm{v}$ Jasenu pod naselji, onesnaženje tako s kmetijskih zemljišč kot zaradi neprečiščenih komunalnih odplak pa iste dni v Sevščku, Potoku v Podgrajah in neimenovanem potoku v Vrbici pod naselji. Novembra je bila mejna vrednost $0,1 \mathrm{mg} / \mathrm{l}$ dosežena v Potoku v Podgrajah in neimenovanem potoku $\mathrm{v}$ Vrbici pod naselji. Vrednosti so se s povečanjem padavin in pretokov na vseh pritokih zmanjševale.

\section{Sklep}

Hidrološke značilnosti povirja Reke, ki obsega območje doline Reke med Dletom in Ilirsko Bistrico ter del Snežniške planote, pomembno vplivajo na hidrološke značilnosti spodnjega dela porečja. Zaradi vpliva višje ležeče kraške Snežniške planote je količina padavin v tem delu največja, izhlapevanje pa najmanjše. Posledično odteče iz povirnega dela največji delež vode v celotnem porečju.

Rezultati meritev fizikalno-kemijskih značilnosti desnih pritokov Reke kažejo, da med pritoke z značilnostmi kraškega pretakanja lahko z gotovostjo štejemo zgolj Pilo, deloma pa tudi prvi Jark v Jasenu, ostale pritoke, na katerih smo opravili meritve, pa ne. Pila je edini stalen vodotok, kar je značilnost kraških izvirov, majhno spremenljivost pa izkazujeta tudi temperatura in SEP vode, kar kaže, da se podzemne vode $\mathrm{v}$ zaledju njenega izvira pretakajo po razvejani mreži podzemnih kanalov in se posledično v podzemlju zadržujejo dlje časa. Podobne so značilnosti tudi prvega Jarka v Jasenu.

Rezultati meritev hkrati kažejo na slabše kakovostno stanje desnih pritokov pod naselji. Največji pokazatelji onesnaženja pritokov pod naselji so izmerjene vrednosti nitratov, amonijevih ionov in fosfatov, ki so občasno presegale mejne vrednosti. Največje razlike v vrednostih parametrov nad in pod naselji kažeta Potok v Podgrajah in neimenovani potok v Vrbici. Na slednjih so bile izmerjene najvišje vrednosti nitratov $\mathrm{v}$ vodi ter presežene običajne koncentracije amonijev ionov in fosfatov v površinski vodi. Hkrati je bilo na obeh pritokih pod naselji raztopljenega najmanj kisika v vodi. Na ostalih pritokih so bile povišane koncentracije hranil (amonijev in fosfatov) izmerjene še v Pili, Potoku v Trpčanah, Vrbovskem potoku, prvem Jarku v Jasenu in Sevščku pod naselji. Onesnaženje desnih pritokov v povirju Reke ni tako izrazito, da bi lahko bistveno vplivalo na kakovostno stanje Reke dolvodno, vendar pa je prisotno. Najvažnejši ukrep, ki bi ga morali v naseljih brez urejenih kanalizacijskih omrežij v dolini Reke uresničiti, je, da bi pretočne greznice zamenjali z nepretočnimi in jih praznili v skladu s predpisi. 
Tam, kjer greznic ni, pa bi jih bilo treba zgraditi. V prihodnosti bo treba naselja tudi kanalizacijsko opremiti in jih priključiti na javni kanalizacijski sistem s centralno čistilno napravo.

Predvsem bi se bilo treba resneje posvetiti vprašanjem varstva vodnih virov, ki so zajeti za vodooskrbo. Treba bi bilo opraviti hidrogeološke raziskave, na podlagi katerih bi jim določili vodooskrbna območja z vodovarstvenimi pasovi in režimi. Že izdelan predlog (Petauer in sodelavci 2002) o tem, bi bilo treba pregledati, ga po potrebi dopolniti in ga v najkrajšem možnem času tudi uveljaviti.

\section{Viri in literatura}

Digitalne informacije o vodah. Agencija Republike Slovenije za okolje. Ljubljana, 2001.

Digitalni model višin 25. Geodetska uprava Republike Slovenije. Ljubljana, 2005.

Državna topografska karta Republike Slovenije 1:50.000, list Ilirska Bistrica. Geodetska uprava Republike Slovenije. Ljubljana, 2003.

Frantar, P., Hrvatin, M. 2005: Pretočni režimi v Sloveniji med letoma 1971 in 2000. Geografski vestnik 77-2. Ljubljana.

Frantar, P. 2007: Geografski pregled vodne bilance Slovenije 1971-2000 po glavnih porečjih. Acta geographica Slovenica 47-1. Ljubljana. DOI: 10.3986/AGS47102

Gams, I. 2003: Kras v Sloveniji v prostoru in času. Ljubljana.

Hidrografska območja. Agencija Republike Slovenije za okolje. Ljubljana, 2011.

Hidrogeološke značilnosti. Agencija Republike Slovenije za okolje. Ljubljana, 2007.

Kolbezen, M., Pristov, J. 1998: Površinski vodotoki in vodna bilanca Slovenije. Ljubljana.

Kovačič, G. 2001: Okoljevarstvena problematika vodooskrbnih območij občine Ilirska Bistrica. Diplomsko delo, Filozofska fakulteta Univerze v Ljubljani. Ljubljana.

Kovačič, G. 2003: Kraški izviri Bistrice (JZ Slovenija). Annales: Series historia naturalis 13-1. Koper. Kranjc, A., Mihevc, A. 1989: Poplavni svet ob Notranjski reki. Geografski zbornik 28. Ljubljana.

Petauer, D., Juren, A., Štucin, P., Ilovar, S. 2002: Strokovne podlage za zaščito vodnih virov občine Ilirska Bistrica. GEOOKO in GeoSi. Ljubljana.

Petrič, M. 2009: Pregled sledenja voda z umetnimi sledili na kraških območjih v Sloveniji. Geologija 52-1. Ljubljana. DOI:10.5474/geologija.2009.013

Plut, D. 2000: Geografija vodnih virov. Ljubljana.

Podatki o dnevnih padavinah na padavinskih postajah Mašun, Juršče in Podgrad pri Ilirski Bistrici v obdobju 1. 8. 2012-31. 1.2013. Agencija Republike Slovenije za okolje. Ljubljana, 2013.

Podatki o dnevnih pretokih in vodostajih na vodomernih postajah Trpčane, Trnovo in Cerkvenikov mlin (Reka) v obdobju 1.8.2012-31.1.2013. Agencija Republike Slovenije za okolje. Ljubljana, 2013.

Podatki o srednjih, najmanjših nizkih in najvišjih visokih mesečnih in letnih pretokih v obdobjih merjenj na vodomernih postajah Trpčane, Trnovo in Cerkvenikov mlin (Reka). Agencija Republike Slovenije za okolje. Ljubljana, 2012.

Povprečna letna višina korigiranih padavin 1971-2000. Agencija Republike Slovenije za okolje. Ljubljana, 2007.

Pravilnik o pitni vodi. Uradni list Republike Slovenije 19/2004, 35/2004, 26/2006, 92/2006, 25/2009. Ljubljana.

Prebivalstvo po velikih in petletnih starostnih skupinah in spolu, naselja, Slovenija, polletno. Statistični urad Republike Slovenije. Ljubljana, 2012.

Raster realne evapotranspiracije v Sloveniji $100 \times 100$ m, 1971-2000. Agencija Republike Slovenije za okolje. Ljubljana, 2008.

Raster specifičnega odtoka $100 \times 100$ m, 1971-2000. Agencija Republike Slovenije za okolje. Ljubljana, 2008.

Ravbar, N. 2011: Hidrološke značilnosti kraških vod. Občina Ilirska Bistrica: monografija. Ilirska Bistrica.

Razvodnice. Agencija Republike Slovenije za okolje. Ljubljana, 2007. 
Rojšek, D. 1987: Fizičnogeografske značilnosti in naravne znamenitosti porečja Notranjske Reke. Varstvo narave 13. Ljubljana.

Šebenik, I., Kladnik, D. 1999: Brkini in dolina Reke. Slovenija: pokrajine in ljudje. Ljubljana.

Šikić, D., Pleničar, M., Šparica, M. 1972: Osnovna geološka karta SFRJ $1: 100.000$, list Ilirska Bistrica. Zvezni geološki zavod. Beograd.

Šikić, D., Pleničar, M. 1975: Osnovna geološka karta SFRJ 1:100.000, tolmač lista Ilirska Bistrica. Zvezni geološki zavod. Beograd.

Urbanič, G., Toman, M. J. 2003: Varstvo celinskih voda. Ljubljana.

Uredba o emisiji snovi in toplote pri odvajanju odpadnih vod v vode in javno kanalizacijo. Uradni list Republike Slovenije 47/2005, 45/2007, 79/2009, 64/2012. Ljubljana.

Uredba o oskrbi s pitno vodo. Uradni list Republike Slovenije 88/2012. Ljubljana.

Zakon o vodah. Uradni list Republike Slovenije 67/2002, 110/2002, 2/2004, 41/2004, 57/2008, 57/2012, 100/2013. Ljubljana.

\section{Summary: Hydrogeographical characteristics and the quality of watercourses in the Reka River headwaters}

(translated by Primož Kovačič)

The Reka River basin covers the south-western part of Slovenia. The headwater part of the basin is hilly area of Dleto, where small streams from several gullies and ravines, formed in flysch rocks, merge in one river.

The objective of this study is to present in detail hydrogeographic characteristics of the upper part of the Reka basin, especially those of its right-bank tributaries, as well as to determine whether they show any characteristics, which are typical for karst springs. Furthermore, an assessment of water quality of the Reka and its right-bank tributaries in its upper course is discussed.

The upper part of the Reka River basin, stretching from the source of the Reka to its confluence with the Molja tributary, covers an area of $143.3 \mathrm{~km}^{2}$ or $31.7 \%$ of the whole Reka drainage basin in Slovenia. The largest part of the Reka upper drainage basin encompasses the Snežnik karst plateau. The plateau is a deeply karstified area, built mostly of Cretaceous and Jurassic limestones, where karst-fissured porosity prevails, meaning that watersheds are difficult to delineate. An underground watershed between several karst springs and also between the Adriatic and Black Sea basins is found in the area of the plateau. Although the local erosion base of the Reka valley is among the lowest $(400 \mathrm{~m})$, the majority of abundant precipitation (around 2,300 $\mathrm{mm}$ ) runs towards the catchment area of the rivers Ljubljanica (555 $\mathrm{m}$ ) and Riječina ( $350 \mathrm{~m}$; in Croatia). The topographic watershed can be easily determined on the left edge of the Reka upper course in the area of Jelšanska brda. In the west, the Snežnik plateau borders to the Eocene flysch sediments (consisting of shale, marlstone, sandstone, breccia and conglomerate) of the Reka valley. The plain along the river and its major tributaries is covered with Quaternary alluvial sediments, where an intergranular aquifer is formed. Shallow aquifers with intergranular and fissured porosity of low abundance are formed in flysch rocks.Drainage density on practically impermeable flysch rocks is $2.4 \mathrm{~km} / \mathrm{km}^{2}$. The Reka belongs to the group of rivers with a Mediterranean pluvial discharge regime. Its higher discharges are typical for the colder part of the year and its main discharge peak corresponds to the largest quantity of precipitation in the catchment area in November. Below average quantities of water occur between May and September, with the lowest waters in July or August. The mean annual discharge of the Reka at the Trpčane gauging station in the period 2000-2010 was $1.32 \mathrm{~m}^{3} / \mathrm{s}$, the highest $139 \mathrm{~m}^{3} / \mathrm{s}$ and the lowest $0.0 \mathrm{~m}^{3} / \mathrm{s}$. The ratio between average minimum and average maximum discharge is $1: 105$. In the period 1971-2000, the mean annual precipitation in the upper part of the Reka river basin was estimated at $1,600 \mathrm{~mm}$ and the specific runoff at $51 \mathrm{l} / \mathrm{s} / \mathrm{km}^{2}$, with a runoff coefficient of around $69 \%$. 
The Reka has 27 right-bank tributaries in its upper course (Table 1). In general, the lengths of watercourses do not exceed $2 \mathrm{~km}$. Due to the relief characteristics, the stream gradients of the tributaries are very high (up to $263 \%$ ), which reflects in their high erosive power. The surface areas of the tributaries' catchments range between 0.08 and $4.27 \mathrm{~km}^{2}$. It is possible that some of the right-bank tributaries catchments partly continue into the karst aquifer of the Snežnik plateau, but for the majority of them this does not seem to be the case.

Meteorological and hydrological data was obtained from the Slovenian Environment Agency (ARSO). The fieldwork comprised (i) in situ measurements of selected physico-chemical parameters of water (water temperature, electric conductivity, $\mathrm{pH}$, dissolved oxygen concentration, nitrate concentration) in the Reka River and its tributaries on 19 different locations, and (ii) sampling of water at the same locations for subsequent simple chemical analysis (concentrations of nitrate, ammonium and phosphates) carried out by using handy water analysis test kits. The study was carried out under four different hydrological conditions between August 2012 and January 2013. The first measurements were carried out under low water conditions, when only the Reka and its tributary Pila were active. The second measurements were performed after first intensive rains in mid-October, following an extended dry period. The third measurements were carried out after an extended rainy period (232-366 mm of precipitation in 11 days) at the beginning of November, and the last ones were carried out at the end of January, following an extended, but less intensive rainy period.

The results of the measurements of physico-chemical properties of the Reka right-bank tributaries (Table 2) indicate that only the Pila and possibly the Jark show characteristics typical for karst springs. Namely, the Pila is the only permanent right-bank tributary of the Reka. The temperature and electric conductivity (EC) of its water show very low annual variability $\left(0.2^{\circ} \mathrm{C}\right.$ and $16 \mu \mathrm{S} / \mathrm{cm}$ respectively), which is typical for karst springs that recharge through a system of underground water channels. Similar features are also characteristic for the Jark tributary. The lowest EC values were measured in the Reka $(118-362 \mu \mathrm{S} / \mathrm{cm})$. Low concentrations of dissolved particles in the Reka in its upper course correspond to the short retention time of percolating precipitation water in only thin or, in some places, almost entirely absent layers of soil and sediment cover, causing quick runoff from the area. Relatively high EC values $(568-689 \mu \mathrm{S} / \mathrm{cm}$ ) measured in some of the right-bank tributaries (e.g. the Vrbovski potok, the Goričnik, the Potok-Trpčane) could be partly explained by hydrological conditions at the time of the measurements; washing of old, highly saturated water out of the system after a prolonged dry period.

In general, the results of the measurements show that the water quality of the right-bank tributaries is lower at the sampling points located downstream from the settlements in comparison to those located upstream. The most evident indicators of pollution originating from the settlements are measured values of nitrate, ammonium and phosphate ions. The biggest differences in the measured values of these parameters between the different sampling points located upstream and downstream from the settlements were detected in the Potok tributary at the settlement Podgraje and a tributary at the settlement Vrbica. At the latter, the highest levels of nitrate in water were measured that exceeded the normal concentration of ammonium ions and phosphate in surface waters. At both sampling points, the lowest concentrations of dissolved oxygen in water were measured, i.e. $7.9 \mathrm{mg} / \mathrm{l}$ and $6.4 \mathrm{mg} / \mathrm{l} \mathrm{respectively.}$ At the other sampling points of the right-bank tributaries, higher concentrations of nutrients (ammonium and phosphate) were measured only in the Pila, Sevšček, Jark, Vrbovski potok and Potok-Trpčane tributaries.

Pollution of the right-bank tributaries of the Reka River in the upper part of its basin is not so strong to significantly affect the water quality of the Reka; however it is present. The most important protective measure to be implemented almost instantly is to ensure the water-tightness of septic tanks and their maintenance according to regulations. As soon as possible, sewage systems should be built in all of the settlements and connected to the central sewage system with its central wastewater treatment plant. Serious efforts should also be made to address issues of protection of the sources in the upper part of the Reka River basin which are tapped for the drinking water supply of the local population. 
